\title{
Anna Palusińska
}

Katolicki Uniwersytet Lubelski Jana Pawła II anna.palusinska@kul.lublin.pl

\section{TEORIA PARTYCYPACJI W MYŚLI \\ GRZEGORZA PALAMASA}

Grzegorz Palamas w swoich dziełach podejmuje problem relacji człowieka, jako bytu stworzonego i cielesno-duchowego, do Boga-Stwórcy. Stawia pytanie, czy człowiek może stać się uczestnikiem wieczności Boga, czy też Bóg pozostaje dla niego zawsze absolutnie transcendentny i nieosiągalny? Jakie są drogi poznania Boga? Czy jedynym sposobem na dotarcie do wiedzy o Bogu jest filozofia i naturalny rozum? Palamas w swoim nauczaniu wyraża wielki optymizm, ponieważ twierdzi, że chrześcijanin nie tylko może w sposób bezpośredni poznać Boga, ale jest również w stanie partycypować w Bożych działaniach i doskonałościach. Uczestnictwo w tych Bożych energiach jest według Palamasa pełnią ludzkiego życia.

Grzegorz Palamas był bizantyńskim XIV-wiecznym teologiem, nieznanym na zachodzie Europy w czasach jemu współczesnych i mało znanym również obecnie. Dla Kościoła wschodniego natomiast jego nauczanie stanowiło i do dzisiaj stanowi filar teologii prawosławnej oraz jest podstawą dla formułowania twierdzeń teologicznych. Palamas jest autorem swoistej filozoficzno-teologicznej syntezy opartej o osobiste mistyczne doświadczenie modlitwy hezychastycznej, praktykowanej przez atoskich mnichów w Bizancjum. Dowodzi on, wbrew bizantyńskim humanistom, że człowiek może doświadczyć tego, co niestworzone i wieczne, ponieważ Bóg objawia się stworzeniu $\mathrm{w}$ swoich proodoi - wyjściach - będących Bożą epifanią. Człowiek w tym życiu, twierdzą hezychaści, może partycypować w wiecz- 
ności Boga, tak jak w Jego świętości i innych energiach Bożych, ponieważ energie (energeiai), czyli działania Boga, objawiają Boga stworzeniu. Obecna u świętego Grzegorza Palamasa maksymalistyczna wizja relacji pomiędzy Bogiem a człowiekiem jest inspiracją nie tylko dla mnichów chcących podążać drogą hezychazmu, ale również dla uczonych, którzy czytając jego dzieła i badając jego myśl, stają się palamitami.

Grzegorz Palamas zdecydował się na życie monastyczne w klasztorze na górze Atos, lecz musiał je porzucić, ponieważ został wezwany do obrony hezychastów zaatakowanych przez Barlaama z Kalabrii. Mnisi za pomocą hezychastycznej metody modlitwy chcieli osiągnąć hezychię - ciszę, bezruch poznawczy, zawieszenie poznania zmysłowego i umysłowego, „ciemność niewiedzy", która umożliwia objawienie się Boga, poznanie ponadnaturalne i mistyczne. Barlaam uważał, że hezychaści są szaleńcami i oszustami, gdyż twierdzą, że człowiek może w ziemskim życiu bezpośrednio doświadczyć Boga, a także może ziemskimi oczami zobaczyć światło Przemienienia - to samo, które zobaczyli apostołowie na górze Tabor. Barlaam akceptował racjonalne i naturalne poznanie Boga, wyznaczone przez reguły filozofii, dlatego też dopuszczał jedynie poznanie Boga pośrednie, polegające na wnioskowaniu o Bogu jako o Pierwszej Przyczynie świata. Palamas natomiast przeciwstawiał się autonomiczności filozofii, twierdząc, że rozum bez kryterium, jakim są prawdy wiary, może błądzić i sam nie wystarcza, aby poznać prawdy ponadnaturalne. W swych dziełach broni uzasadnienia i systematyzacji hezychazmu i - pomimo zastrzeżeń do wiedzy filozoficznej - używa jako narzędzi schrystianizowanych pojęć filozoficznych, budując tym samym nowy gmach bizantyńskiej myśli teologiczno-filozoficznej, który w wielu punktach przekracza granice wyznaczone przez helleńską pogańską filozofię. Można powiedzieć, że nauczanie Grzegorza Palamasa jest rekapitulacją całej bizantyńskiej teologii oraz bizantyńskiej tradycji filozofii scholastycznej związanej z doktryną chrześcijańską.

\section{Spór hezychastyczny}

Kontrowersja palamicka dotyczy rozumienia mistyki chrześcijańskiej oraz interpretacji tradycji patrystycznej. Grzegorz Palamas i Barlaam zajmują $\mathrm{w}$ tej debacie opozycyjne stanowiska. Kalabryjczyk twierdzi, że człowiek może poznać Boga jedynie pośrednio - poprzez stworzenie; może, na przykład za pomocą metod filozofii, rozpoznać obecność Stwórcy w świecie, ale nie może bezpośrednio stać się uczestnikiem tego, co niestwo- 
rzone ${ }^{1}$. Chociaż Barlaam w pierwszej fazie sporu wydaje się uznawać intelektualną iluminację za źródło wiedzy i umysłowej metanoi, to później ogranicza źródła poznania do tego, co naturalne i osiągane na drodze rozumowego poznania.

Palamas w swojej postawie ograniczającej możliwości filozofii idzie za chrześcijańskimi autorami, którzy musieli się zmierzyć z dziedzictwem kultury greckiej i jej filozofii. Dla Ojców Kościoła filozofia miała charakter propedeutyczny wobec wiedzy chrześcijańskiej, a więc mogła być akceptowana w granicach prawd wiary, nawet pomimo tego, że wiele jej rozwiązań uważano za absurdalne, na przykład przypisywanie boskości materialnym zasadom, takim jak woda, ogień czy powietrze, a przede wszystkim neoplatońskie przekonanie o metempsychozie. Powiązanie wiary z naukową terminologią stworzyło $\mathrm{w}$ epoce wczesnochrześcijańskiej wiele napięć, albowiem z jednej strony Arystotelesowskie pojęcia substancji i natury nie dały się bez korekty zastosować do opisu zagadnień chrystologicznych i trynitarnych, a ich interpretacja stała się źródłem nieprawowiernych rozwiązań, jak tryteizm Jana Filopona, z drugiej natomiast - orygenizm i neoplatonizm implikowały angelizm w antropologii i deprecjację ludzkiej cielesności. Myśl patrystyczna jest więc budowaniem nowej filozofii, $\mathrm{w}$ wielu punktach burzącej starożytne schematy i proponującej nowy obraz relacji pomiędzy światem i Bogiem. Grzegorz Palamas należy również do tego nurtu, albowiem jego rozwiązania godzą w neoplatońską koncepcję Jednego, Platońską antropologię i Arystotelesowski antropocentryzm.

Napięcie pomiędzy racjonalizmem, związanym z maksymalistycznymi ambicjami filozofii, a teologią chrześcijańską, wyrastającą z doświadczenia mistycznego i monastycznego życia, przebiega przez wszystkie epoki trwania Bizancjum i jest charakterystyczne również dla sporu palamickiego. Palamas nie przyznaje filozofii wielkiego znaczenia, jednak nie z powodu postawy fideistycznej, ale dlatego że uznaje, iż poza przyrodzonym rozumem i naturalnym poznaniem istnieje inne źródło wiedzy, polegające na doświadczeniu i partycypacji. Występując przeciwko barlaamitom, pokazał, że doświadczenie mistyczne i modlitwa hezychastyczna są źródłem bezpośredniego poznania Boga, do którego nie może dojść filozofia posługująca się metodą poznania dyskursywnego. Hezychazm jest wyrazem chrześcijańskiego przekonania o nieautarkiczności człowieka, zwłaszcza na płaszczyź-

${ }^{1}$ Zob. A. Palusińska, Wiedza grecka a mądrość chrześcijańska. Drogi poznania Boga, czyli spór o mistykę Grzegorza Palamasa z Barlaamem z Kalabrii, w: Duchowość Dalekiego Wschodu a chrześcijaństwo. Dialog czy konfrontacja?, t. 6, red. I. Kamiński, J. Kulwicka-Kamińska, J. Perszon, Toruń 2014, s. 81-94. 
nie moralnej, ponieważ doświadczenie Boga, dokonujące się jako uczestnictwo w Bożej łasce i w Bożym działaniu, jest źródłem każdej doskonałości, a więc również moralnego dobra.

Grzegorz Palamas sformułował swoją naukę o modlitwie hezychastycznej jako osoba zanurzona $\mathrm{w}$ monastycznej i mistycznej tradycji Kościoła wschodniego ${ }^{2}$. Myśl Palamasa, z jednej strony, za pomocą języka i pojęć filozoficznych nawiązuje do intelektualnego bagażu antyku, z drugiej natomiast, opierając się przede wszystkim na Ojcach Kościoła, chce on zbudować mądrość chrześcijańską - wiedzę wewnętrzną, która nie będzie zależna od żadnego systemu filozoficznego. Interpretacja wiary przez Grzegorza Palamasa jest tak radykalna, że niektórzy ówcześni oraz XX-wieczni teologowie uważają, iż Palamas wprowadza novum tak zasadnicze, że nie może być na nie zgody.

Palamas, broniąc hezychastów, twierdzi, że człowiek poprzez partycypację staje się uczestnikiem tego, co Boskie. Może partycypować w niestworzonej świętości Boga, a więc również mieć swój udział w wieczności, ponieważ każda z partycypowalnych energii Boga posiada cechę Bożej natury - jest wieczna i niestworzona. Wieczność nie jest więc obiecaną rzeczywistością, której człowiek może dostąpić po śmierci, w innym sposobie egzystencji, ale jest realnością, w której może uczestniczyć już teraz, w życiu doczesnym, podążając drogą chrześcijańskich przykazań i hezychastycznej modlitwy.

\section{Partycypacja w modlitwie}

Grzegorz Palamas uzasadnia swoją doktrynę partycypacji, rozwijając teorię rozróżnienia Bożej energii (energeia) i Bożej istoty (ousia). Idąc za Maksymem Wyznawcą, Palamas wyróżnia istotę (czyli fysis - naturę) i jej działanie (energeia - energię). Rozróżnienie to odegrało istotną rolę w sporze monoteletyckim i pozwoliło Maksymowi zachować ideę osobowej jedności Jezusa Chrystusa oraz dwoistości jego działania: boskiego i ludzkiego. O ile jedność osobową konstytuuje hipostaza, a więc indywiduum podmiotujące wszystkie indywidualne (hipostatyczne) cechy, o tyle działanie tego podmiotu wypływa z natury, określa ją i objawia. Jeśli zatem Chrystus posiadał dwie natury, to także jego działanie odzwierciedla tę dwoistość - działanie wypływające $\mathrm{z}$ natury boskiej jest działaniem boskim, a to wypływające

${ }^{2}$ K. Leśniewski, Hezychazm - skarb chrześcijańskiego Wschodu, w: Duchowość Dalekiego Wschodu..., op. cit., s. 57-80. 
z natury ludzkiej jest działaniem ludzkim³ ${ }^{3}$ Palamas, odnosząc tę zasadę do Boga i Jego działania, twierdzi, że energia (działanie), z tego powodu, że jest zapodmiotowana w naturze Boskiej, posiada również jej cechy. Jest więc niestworzona i wieczna, bo taka jest też istota (ousia) Boga - źródło i podmiot działania. O ile nie możemy ująć w żadnym akcie poznawczym Bożej istoty, ponieważ istnieje ona ponad poznaniem i ponadsubstancjalnie, o tyle Boże moce i działania są partycypowalne i mogą być przedmiotem mistycznego doświadczenia.

Palamas w swoim nauczaniu o energiach Bożych, które są różne od transcendentnej istoty Boga, podąża za tradycją patrystyczną, a w szczególności za Dionizym Areopagitą, Maksymem Wyznawcą i Janem z Damaszku. Imiona Boże u Dionizego stanowią katafatyczną teologię wypływającą z Objawienia - orzekają one o Bogu, o tym, kim Bóg jest. Bóg jest źródłem proodoi - wyjść, w których objawia się stworzeniu; jest epifanią. Ale imiona Boga nie mogą w sposób pełny wyrazić bytu Bożego, ponieważ Boskość transcenduje każde pozytywne określenie Boga. Według Dionizego, transcendencja Boga jest tak radykalna, że Boskość transcenduje nawet Trójcę. Dlatego też Dionizy może z naciskiem powiedzieć, że Bóg jest poznawalny i niepoznawalny zarazem, a więc głosić antynomię Boga, który jest dostępny i pojęty (w tym, co objawione), ale też w swojej Boskości jest całkowicie transcendentny i nieujmowaly ${ }^{4}$.

Nauka o energiach jest sposobem na zagwarantowanie chrześcijańskiej wiary w możliwość osiągnięcia przebóstwienia, świętości, uświęcenia i mądrości, a więc doskonałości, których źródłem jest Bóg, ponieważ człowiek może partycypować w Bożych energiach. Jednocześnie zaś Bóg ciągle pozostaje dla niego od strony swojej istoty niepoznawalny, całkowicie i absolutnie transcendentny.

Grzegorz Palamas, ukazując partycypowalny charakter Bożego działania (energii), podważa tym samym starożytny antropocentryzm. Antyczna filozofia bowiem widziała człowieka jako tego, kto może samodzielnie, swoim własnym wysiłkiem i swoją mocą osiągnąć moralną doskonałość, urzeczywistnić cnoty moralne i cnoty noetyczne, na przykład mądrość. Arystoteles w swoich tekstach etycznych rozwija koncepcję samorealizacji się człowieka dzięki panowaniu rozumu nad zmysłową naturą i osiąganiu cnoty. Jest to ta sama myśl, którą Sokrates wyraził w idei enkratei: rozum może ograniczać i panować nad zmysłowymi impulsami i popędami, wystarcza też do zdo-

\footnotetext{
${ }^{3}$ A. Louth, Maximus the Confessor, London - New York 1996.

4 Pseudo-Dionizy Areopagita, Imiona Boskie, w: idem, Pisma teologiczne, tłum. M. Dzielska, Kraków 2005, s. 217-324.
} 
bycia szczęścia i zrealizowania wolności, a także jest jedynym warunkiem cnoty.

Filozofia chrześcijańska natomiast naucza o innej kondycji człowieka, wynikającej z prawdy o grzechu. Samodzielne osiągnięcie doskonałości staje się niemożliwe $\mathrm{w}$ przypadku, gdy ludzka natura została złamana przez grzech. Człowiek potrzebuje Bożego działania nie tylko do tego, aby osiągnąć szczęście, ale również aby osiągnąć moralną doskonałość. Przebóstwienie ludzkiej natury i partycypacja $\mathrm{w}$ boskości jest więc sposobem na spełnienie się człowieczeństwa, życie w łasce Boga i realizację Bożego zamysłu o człowieku. Grzegorz głosi:

Wszyscy Ojcowie rozpoczęli więc [głoszenie - przyp. tłum.] nauki nie od stworzonej swej natury, ale od tego, że święci są bogami i królami. Zaś królewskość, boskość i świętość, którą mają, jest niestworzona i niemająca początku, albowiem uczestniczą oni w niestworzonym królestwie Boga, a nie w jakimś innym; w ponadziemski sposób jednoczą się z wiecznym, jedynym, świętym Bogiem i Królem wszystkiego. Cóż zatem? Czyż czymś innym jest boskość, czymś innym królestwo, a czymś innym świętość? Otóż czymś innym jest znaczenie każdego z tych słów, ale nie one same, ponieważ są mocami i energiami jednego Boga 5 .

Palamas twierdzi, że żaden byt nie jest dla siebie samego źródłem Doskonałości. Każdy byt istnieje zawsze jako niepełny, niedoskonały i stający się. Człowiek więc nie może być dla siebie przyczyną życia, świętości, Doskonałości i uświęcenia. Partycypacja w Życiu, Świętości, Istnieniu - które są pełnią doskonałości, ponieważ istnieją na sposób Boskiej natury - umożliwia osiągnięcie i realizację tych doskonałości przez człowieka. Energie Boże są sposobem nie tylko poznania Boga, który się w nich objawia, ale również sposobem realizacji Bożego planu wobec człowieka. Człowiek nie tylko musi od Boga otrzymywać dary istnienia, dobra, życia, piękna, świętości, ale również wszystkie inne rzeczy stworzone partycypują w Bożych działaniach i są konstytuowane poprzez tę partycypację. Nie ma bowiem niczego, co nie zależałoby w swej egzystencji i strukturze od Boga. Partycypacja w niestworzonych Bożych aktach nie implikuje jednakże zmieszania natury stworzonej i niestworzonej, albowiem Boskie dary (energie) aktualizują i urzeczywistniają doskonałości w stworzeniu, jako ich przyczyna. W teorii partycypacji Palamas afirmuje nieustanną ingerencję Boga w swoje stworzenie, ciągłe Boskie stwarzanie wszelkiego bytu i działanie „boskostwórczej”

${ }^{5}$ Grzegorz Palamas, Obrona szczegótowa, 18, tłum. I. Zogas-Osadnik, w: Palamas, Bułgakow, Łosiew. Rozważania o religii, imieniu Bożym, tragedii filozofii, wojnie $i$ prawach człowieka, red. L. Kiejzik, Warszawa 2010, s. 140-141. 
opatrzności, ponieważ patrystyczna idea partycypacji, którą podziela również i Grzegorz, oznacza Boskie działanie w tym, co nie jest Bogiem ${ }^{6}$.

Wszelkie doskonałości Boże i cechy Boga - które Palamas nazywa energiami bytującymi wokół Bożej istoty - są wieczne, a więc nie mają początku w czasie. Nie zostały stworzone, lecz są „wychodzeniami” Boga w kierunku stworzenia, poznawalnymi, partycypowalnymi i dostępnymi dla ludzkiego doświadczenia:

Nie tylko w przypadku mądrości, lecz także życia i dobra, świętości i nieśmiertelności, i w ogóle wszystkich bytów zachodzi następująca prawidłowość: jedne zostały stworzone i wzięły początek jako partycypujące, inne, ukazujące się jako partycypowane, są niestworzone i bez początku, ponieważ są wiecznymi boskimi energiami, zawsze złączonymi $\mathrm{z}$ wiecznie wszechmocnym i doskonałym Bogiem i Władcą wszystkiego, który ze względu na swą niepartycypowalną dla wszystkich istotę przewyższa i jest wyżej także od tych partycypowanych [właściwości - przyp. tłum.], które z natury odwiecznie są oglądane przez myśl jako będące wokół Niego7

Natomiast nauczanie Barlaama, ujawniające kontekst filozofii tomistycznej, ukazuje Boga jako całkowicie prostego. Tomasz bowiem podkreśla absolutną tożsamość istoty Boga i wszystkich Jego atrybutów, a dowodzenie istnienia Boga przeprowadza poprzez skonstruowanie aposteriorycznych rozumowań, w których Bóg okazuje się konieczną racją $\mathrm{w}$ metafizycznym wyjaśnianiu przygodnego istnienia bytów stworzonych oraz aktualnym koniecznym źródłem wszelkiej doskonałości. Tożsamość istoty i istnienia w Bogu jest całkowita i pozwala jedynie na myślowe rozróżnienie Bożych atrybutów, które realnie utożsamiają się z Bożą istotą ${ }^{8}$. Za tą intuicją Tomasza idzie Kalabryjczyk, ponieważ neguje realną nietożsamość istoty i działania Boga i twierdzi, że Stwórca objawia się w swoim stworzeniu tylko jako jego źródło poprzez znaki i symbole, które mają charakter stworzony. Wszystko więc to, czego człowiek może doświadczyć, jest - według Barlaama - stworzeniem, toteż Bóg jest absolutnie transcendentny i prosty, nieosiągalny dla ludzkiego poznania i doświadczenia.

Dokonane przez doktora hezychastycznego wyróżnienie w Bogu transcendentnej i niepoznawalnej istoty i poznawalnych, partycypowalnych energii stało się przyczyną ataków na palamizm i oskarżeń o wprowadzanie czwartej osoby do Trójcy Świętej, a tym samym dokonania nieuprawnionego podziału w Bogu. Grzegorz Palamas jest jak najdalszy od podważania chrześcijańskich dogmatów wiary. Energie Boże nie powodują żadnego roz-

6 T.T. Tollefsen, Activity and Participation in Late Antique and Early Christian Thought, Oxford 2012, s. 189-191.

${ }^{7}$ Grzegorz Palamas, Obrona szczegółowa, 41, op. cit., s. 154.

8 M.A. Krąpiec, Metafizyka, Lublin 1988, s. 503-506. 
bicia ani podziału w Bogu, ponieważ nie posiadają własnej hipostazy, a więc nie są odrębnym podmiotem. Są działaniami Boga na zewnątrz i Bożym istnieniem $\mathrm{w}$ świecie stworzonym, ale nie istnieniem substancjalnym:

Ale takie boskie i niebiańskie życie w Bogu żyjących w komunii nierozdzielne jest z życiem Ducha jak, według Maksyma Wyznawcy, i Paweł „żył boskim i wiecznym życiem Zamieszkującego w nim" - takie życie istnieje wiecznie i ma naturę Ducha, który boskostwarza od wieków i sprawiedliwie nazywa się u świętych Duchem i Boskością jako bogostwórczy dar niczym nieodróżniający się od Darującego Ducha; i ono [życie - przyp. A.P.] jest światłem, które odkrywa się w tajemniczym olśnieniu i które jest znane tylko godnym, [światłem - przyp. A.P.] hipostatycznym, nie dlatego, że posiada odrębną hipostazę, ale dlatego że Duch posyła to życie „w hipostazę kogoś", w której jest kontemplowane. Takie ono jest samo we właściwym sensie, whipostazowane, kontemplowane nie samo przez się i nie w swojej istocie, ale w hipostazie $[\ldots]^{9}$.

Według Palamasa, człowiek nie jest zatem zamknięty w kręgu symboli i poznania pośredniego. Nie musi za pomocą filozoficznych analiz poznawać Stwórcy jedynie ze śladów, które On zostawił w stworzeniu, ale ma możliwość bezpośredniego, osobowego spotkania i osobowego doświadczenia Boga w Jego działaniach. Teologia chrześcijańska, tak jak ją rozumie Grzegorz, nie jest logicznym bądź filozoficznym opracowaniem prawd wiary, lecz jest wiedzą wypływającą z osobistego, bezpośredniego spotkania Boga $\mathrm{w}$ modlitwie, zwłaszcza $\mathrm{w}$ modlitwie hezychastycznej. Badania filozoficzne wydają się dla Palamasa niewystarczającą, a nawet niekiedy błędną, metodą poznania Boga. W Triadach pisze:

Gdy słyszysz o oczach duszy, które doświadczają skarbów niebieskich, nie powinieneś uciekać się do rozumu. Ćwiczy się on bowiem w zadowalający sposób zarówno $\mathrm{w}$ rzeczach postrzegalnych, jak w ideach. Jeśli wyobrazisz sobie miasto, którego nigdy nie widziałeś, na pewno nie staniesz się uczestnikiem doświadczenia tylko dlatego, że o nim myślałeś; tak samo nie możesz doświadczyć Boga tylko dlatego, że o nim myślisz lub mówisz. Jeżeli nie masz w sposób materialny złota, jeżeli go nie widzisz oczyma ciała, jeśli go nie ściskasz w dłoniach, znaczy to, że go nie masz, nawet jeśli myśl o złocie tysiąc razy przechodzi ci przez głowę. Tak samo jeśli myślisz tysiąc razy o skarbach Bożych, nie próbując ich doświadczalnie i oczyma ducha, które sięgają dalej niż rozum, nie widzisz nic i nie masz nic Boskiego. Mówiłem o oczach ducha, ponieważ w nich przychodzi moc Ducha, pozwalająca widzieć; jednak całe to święte widzenie Boskiego światła, które oświeca, przekracza same oczy ducha10.

\footnotetext{
${ }^{9}$ Grzegorz Palamas, Triades III, 1, 9 (tłum. własne).

${ }^{10}$ Idem, Triades I, 3, 34. tłum. B. Widła, w: Y. Spiteris, Ostatni ojcowie Kościoła. Kabasilas. Palamas, Warszawa 2006, s. 211.
} 
Niestworzoność przysługuje Bogu jako odwiecznie istniejącemu. Bóg jest nieuprzyczynowany i nie ma początku w czasie. Stworzenie zaś jest uprzyczynowane $\mathrm{w}$ swoim istnieniu i ma początek. Palamas rozważa problem, czy działania Boga i Boże atrybuty mają charakter stworzony, czyli czy są bytami wobec Boga zewnętrznymi. Istotnie, gdyby tak było, bezpośrednie egzystencjalne spotkanie $\mathrm{z}$ Bogiem byłoby niemożliwe. Palamas $\mathrm{w}$ wielu miejscach podkreśla, że Boże energie, w których człowiek partycypuje, są niestworzone. Niestworzoność jest cechą Bożej natury i dlatego staje się także cechą Bożych sił działających:

Czy widzisz, że energia Boga nie jest ani naturą, ani istotą, ale jest naturalna i istotowa? I że jako niestworzona nie jest ona czymś stworzonym, chociaż jest czymś innym niż natura? Ponieważ spośród tego, co mówi się o Bogu, jedne nazwy oznaczają to, czym On nie jest - takie są wszystkie negacje, inne wyrażają boską naturę, takie jak "dobroć", "prostota”, ,życie” i w ogóle każdy rodzaj cnoty; inne znów mają znaczenie mocy i energii, jak „boskość”, ponieważ Bóg przyjął to imię "dlatego, że on wszystko widzi”, to znaczy wie. Cóż zatem? Czy Ten, który poznał wszystko, zanim się stało, rozpoczął kiedyś te działania w czasie? Czy dostrzegasz, że energia jest niestworzona i bez początku, i jest czymś innym niż istota Boga, należąc nie do tego, co jest w Nim, ale do tego, co jest wokół Niego? Czy był taki czas, kiedy z boskiej natury nie wynikało to, co wynika? Tak więc wszystkie one [energie - przyp. tłum] są niestworzone, chociaż żadna $\mathrm{z}$ nich nie jest boską istotą ${ }^{11}$.

Partycypowalność Bożych energii, niestworzonych i odwiecznie istniejących, pozwala na spotkanie człowieka z Bogiem. Gdy Palamas mówi o mistycznym, ponadnaturalnym doświadczeniu Boga, idzie dalej niż wszelkie teorie neoplatońskiej filozofii, ukazujące cel wędrówki duszy wzwyż jako ekstatyczne zjednoczenie z Jednym. Doktor hezychastyczny uważa, że doświadczenie Boga angażuje całego człowieka, nie tylko ducha, ale również jego ciało. Cały człowiek, wraz z ciałem, a nie tylko wysublimowany umysł, uczestniczy w mistycznym widzeniu Boga i cały człowiek może się z Bogiem zjednoczyć, czyli osiągnąć przebóstwienie - theosis. Ciało i związana z cielesnością zmysłowość nie jest dla Grzegorza Palamasa przeszkodą w poznaniu Boga i tym bardziej nie jest niegodnym i złym składnikiem ludzkiej natury. Deprecjację cielesności człowieka rozgłasza tradycja platońska i orygenistyczna, od której Palamas się odżegnuje:

11 Idem, Obrona szczegótowa, 26, tłum. I. Zogas-Osadnik, w: Palamas, Bułgakow, Łosiew..., op. cit., s. 145 . 
My, którzy nosimy w glinianych naczyniach, czyli w naszych ciałach, światło Ojca, w Osobie Jezusa Chrystusa, w którym poznajemy chwałę Ducha Świętego - jakże zamieszkiwanie $\mathrm{w}$ wewnętrznym sanktuarium ciała mogłoby okrywać hańbą nasz umysł? ${ }^{12}$

Wolno więc powiedzieć, że w hezychastycznym doświadczeniu Bożych energii ciało i materia zostały pociągnięte ku temu, co duchowe, i zostały przebóstwione. Stały się w ten sposób uczestnikiem wieczności, zyskując nowy sposób egzystencji.

\section{Wspólne wątki doktryn Jana Dunsa Szkota i Grzegorza Palamasa}

Można zastanowić się, czy palamicka koncepcja Boga, który dopuszcza w Sobie podziały i wielość, ma swój odpowiednik w filozofii zachodniej. Trzeba podkreślić, że nie da się zestawić obok siebie i porównać teologii łacińskiej i bizantyńskiej teologii palamickiej, ponieważ teologia łacińska jest filozoficzną interpretacją prawd wiary, na przykład w przypadku Tomasza z Akwinu jest to interpretacja pozostająca w granicach pojęć przede wszystkim arystotelesowskich. Teologia Palamasa natomiast, ustanowiwszy swym źródłem doświadczenie hezychastycznej modlitwy, stanowi przekroczenie $\mathrm{w}$ wielu ważnych punktach filozofii greckiej. Pomimo tego, że nie da się adekwatnie skonfrontować myśli zachodniej i wschodniej, to można odnaleźć podobny do palamickiego głos w myśli łacińskiej. Koncepcja Palamasa koresponduje $\mathrm{z}$ doktryną Jana Dunsa Szkota, ponieważ zarówno Szkot, jak i Palamas nie zgadzają się z twierdzeniem o absolutnej prostocie Boga.

Racją, dla której Palamas podtrzymuje patrystyczną antynomię mówiącą o Bogu poznawalnym i niepoznawalnym, pojmowalnym i transcendentnym zarazem, jest, po pierwsze, nieautarkiczność ludzkiej natury, która po grzechu pierworodnym ma skłonność do zła i potrzebuje Bożej łaski, aby osiągnąć moralną doskonałość; po drugie - umożliwienie człowiekowi poznania Boga i osobowego spotkania z Nim, spotkania bezpośredniego, uświęcającego i doskonalącego.

Duns Szkot, podważając tomistyczną prostotę i niepodzielność Boga, wprowadza realną różnicę w Bogu, distinctio formalis, ponieważ chce umoż-

12 Idem, Triades, I, 2,2, tłum. K. Leśniewski, w: J. Meyendorff, Święty Grzegorz Palamas i duchowość prawostawna, Lublin 2005, s. 80. 
liwić zbudowanie teologii, która byłaby realnym i rzeczywistym poznaniem Boga. Również z tego powodu Duns Szkot konstruuje swoją doktrynę o jednoznaczności pojęć, chcąc stworzyć prawdziwą teologię katafatyczną, która będzie orzekać o Bogu realne predykaty ${ }^{13}$. Zarówno Szkot, jak i Palamas zaprzeczają absolutnej prostocie i niepodzielności Boga z tego samego powodu. Zamierzają ukazać rzeczywistą podstawę poznania Boga, ponieważ jeśli Bóg byłby niepodzielnie prosty i całkowicie transcendentny, to wiedza o Bogu i o tym, co Boskie, ograniczałaby się do wnioskowania pośredniego i niepewnego.

Można postawić pytanie, dlaczego Palamas nie zgodził się na prostszą i bardziej elegancką teorię Barlaama i odrzucił całkowitą transcendencję Boga i Jego absolutną prostotę, przyjąwszy, obok Bożej istoty, istnienie Bożych energii? Próbując znaleźć racje Palamickiej teorii, trzeba podkreślić, że punktem wyjścia dla Palamasa jest doświadczenie mistyczne, które stało się udziałem jego samego i jego współbraci - hezychastów. Doświadczenie żywego Boga dzięki praktykowaniu modlitwy hezychastycznej dało mu pewność, że celem egzystencji człowieka jest stan przebóstwienia, theosis, który jest osiągany poprzez partycypację $\mathrm{w}$ Bogu, ale nie w Bogu, który przekracza byt ludzki i pozostaje dla człowieka tajemnicą, ale w Bogu, który stał się partycypowalny dla swojego stworzenia, udzielając mu tego, co ma Boski charakter: Dobra, Życia i Świętości.

Palamas z naciskiem stwierdza, że człowiek może stać się uczestnikiem wieczności już w życiu doczesnym, ponieważ doświadczenie samego Boga w darach, których udziela On stworzeniu, jest realne. Przepaść pomiędzy Stwórcą a stworzeniem nie jest tak radykalna, jak widział to Barlaam z Kalabrii. Koncepcja partycypacji w Bogu, w Jego energii, będącej niestworzoną łaską, jest fundamentem nauczania Grzegorza Palamasa i fundamentem przekonania, że człowiek może uczestniczyć w wieczności Boga w sposób rzeczywisty i prawdziwy, a nie jedynie symboliczny.

\section{Gregory Palamas' Theory of Participation}

\section{Summary}

Gregory Palamas creates philosophical and theological synthesis, which originates from his own mystical experience of hesychasm. Palamas claims that man can

${ }^{13}$ E. Zieliński OFMConv, Nieskończoność bytu Bożego w filozofii Jana Dunsa Szkota, Lublin 1980, s. 90-97. 
participate in non created, eternal energeiai of God, which are the external activities of God's uosia - essence. Palamas says that all things participate in God, and they are constituted by this participation, they do not, however, participate in His nature, but in His activity. A man participates in God's eternal activities and in this way can achieve moral and ontic perfectness.

Słowa kluczowe: Grzegorz Palamas, hezychazm, partycypacja, energeia

Keywords: Gregory Palamas, hesychasm, participation, energia

DOI: $10.14746 /$ cbes.2016.15.11 